\title{
Pengaruh Modal Sendiri Dan Kredit Usaha Rakyat (KUR) terhadap Pendapatan Usaha (Studi Pada UMKM di Desa Platihan Kidul Kec. Siman)
}

\author{
${ }^{1}$ Riawan, ${ }^{2}$ Wawan Kusnawan \\ ${ }^{1,2}$ Fakultas Ekonomi, Universitas Muhammadiyah Ponorogo, Indonesia \\ ${ }^{1}$ Email korenpondensi: riawan13awan@gmail.com
}

Recieved: 24-02-2018 | Revised: 24-05-2018 | Accepted: 09-07-2018

\begin{abstract}
Abstrak
Perusahaan dalam menjalankan usahanya, ada beberapa tujuan yang harus dicapai yang salah satunya adalah memaksimalkan keuntungan yang sebesar-besarnya. Keuntungan yang diperoleh tersebut akan dapat meningkatkan kesejahteraan bagi pemilik usaha dan dapat dipergunakan untuk kebutuhan operasi selanjutnya. Teknik pengambilan sampel pada penelitian adalah menggunakan porposive sample dengan menggunakan data primer yaitu membagikan kuesioner pada pelaku usaha UMKM di Desa Platihan Kidul Kec. Siman. Tujuan dalam penelitian ini adalah untuk menguji pengaruh modal sendiri (X1) dan Kredit Usaha Rakyat (X2) terhadap Pendapatan Usaha pada Usaha Mikro Kecil dan Menengah. Hasil penelitian ini menunjukan bahwa modal sendiri dan KUR berpengaruh signifikan terhadap pendapatan usaha disektor UMKM. Hal ini dapat dilihat dari nilai uji T-statistik berada dibawah 0,5. Dengan demikian besar kecilnya modal usaha, sangat mempengaruhi pendapatan usaha. Dimana penggunaan modal kredit sangat membantu para pelaku usaha untuk menambah modal usahannya.
\end{abstract}

Kata Kunci: Modal Sendiri, KUR, Pendapatan Usaha

Saran sitasi: Riawan, R., \& Kusnawan, W. (2018). Pengaruh Modal Sendiri dan Kredit Usaha Rakyat (KUR) Terhadap Pendapatan Usaha (Studi Pada UMKM di Desa Platihan Kidul Kec. Siman). Jurnal Akuntansi dan Pajak, 19(1), 31-37. doi:http://dx.doi.org/10.29040/jap.v19i1.158

DOI: http://dx.doi.org/10.29040/jap.v19i1.158

\section{Pendahuluan}

Usaha Mikro Keci dan Menegah memiliki peran penting dalam perkembangan perekonomian di Indonesia. Pernyataan ini dapat dibuktikan dengan krisis ekonomi yang melanda bangsa Indonesia pada tahun 1998 silam, pemerintah telah mengandalkan Usaha Mikro Kecil dan Menengah untuk meminimalisir atau memperkecil dampak negative krisis ekonomi tersebut.

Menurut Wahyuni (2005) menjelaskan bahwa Usaha Mikro Kecil dan Menengah (UMKM) menjadi isu yang menarik untuk dicermati dan disikapi, hal ini dikarenakan: 1)
Saat krisis ekonomi yang melanda bangsa Indonesia, Usaha Mikro Kecil dan Menengah mampu bertahan sampai saat ini. 2) Perhatian pemerintha terhadap usaha disektor UMKM masih rendah, 3) Jumlah sector Usaha Mikro Kecil dan Menengah sangat banyak dan tersebar disemua tempat sehingga sangat potensial untuk menyerap banyak tenaga kerja, 4) Sector Usaha Mikro Kecil dan Menengah sangat berperan penting dalam memberikan kontribusi terhadap perekonomian nasional.

Keberadaan Usaha Mikro Kecil dan Menengah diharapkan dapat mengatasi serta membe- 
rikan kontribusi terhadap persoalan-persoalan yang dihadapi saat ini, misalnya masalah kemiskinan, pengangguran dan tingkap pendapatan yang diperoleh masih tergolong rendah. Selanjutnya Partomo dan Soejodono (2004) mengemukakan bahwa keberadaan UMKM memberikan peran penting yaitu menjadi sumber kehidupan bagi kalangan masyarakat Indonesia.

Program yang paling populer yang dijalankan oleh pihak perbankan sekarang ini adalah Kredit Usaha Rakyat (KUR) yang diperuntukan bagi pelaku Usaha Mikro Kecil dan Menengah (UMKM). Wiratna dan Utami. (2013) dalam penelitiannya menyatakan bahwa Kredit Usaha Rakyat sangat berperan penting dalam meningkatkan kinerja pada sector Usaha Mikro Kecil dan Menengah (UMKM) hal ini dapat dibuktikan dari adanya perubahan biaya produksi, omzet penjualan, serta keuntungan yang semakin meningkat.

Penggunaan modal sendiri bagi pelaku UMKM lebih cenderung pada pekerjaan yang santai tanpa ada penekanan (Riyanto, 2008). Disamping itu, modal usaha yang dimiliki sangat terbatas sehingga akan kesulitas untuk melakukan ekspansi usaha (Riyanto, 2008). Jika mengacu pada perusahaan-perusahaan besar dalam melakukan kegiatan ekspansi harus didukung dengan permodalan yang kuat. Permodalan yang kuat bukan hanya bersumber pada keuntungan yang diperoleh akan tetapi mereka memanfaatkan permodalan dari luar (jasa keuangan perbankan) sehingga tujuan ekspansi dapat terlaksana dengan baik.

Lembaga keuangan mikro yang berbasis pada jasa keuangan perbankan sebaga sumber modal yang diperuntukan bagi para pelaku UMKM sebaga sumber pendanaan yang cara perolehanya sangat mudah untuk didapatkan. dengan hadirnya Kredit Usaha Rakyat, dimana sebagian besar permodalanya dibantu oleh pemerintah sehingga bunga kredit yang akan dibebankan pada pelaku usaha disektor UMKM sangat kecil. Hal ini akan menjadi kesempatan yang baik untuk para pelaku UMKM untuk memanfaatkan Kredit Usaha Rakyat tersebut sebagai bantuan permodalan dalam meningkatkan pendapatan usaha mereka. Namun disisi lain, permodalan yang dibiayai dengan utang akan memiliki beban tanggungjawab dan resiko yang tinggi oleh pemilik UMKM untuk keberlanjutan usahanya jika utang yang dimiliki tidak mampu untuk dibayar. Hal ini menjadi kekhawatiran sebagian orang dalam memanfaatkan modal usaha melalui utang.

Berdasarkan fenomena di atas, peneliti akan menguji seberapa besar pengaruh Kredit Usaha Rakyat (KUR) dan modal sendiri dalam mempengaruhi pendapatan usaha serta mengamati apakah ada perbedaan pendapatan usaha yang diperoleh ketika di modali dengan modal sendiri dan modal kredit pada sektor UMKM yang ada di Desa Patihan Kidul Kecamatan Siman Ponorogo.

\section{Tinjauan Pustaka}

\section{Usaha Mikro Kecil dan Menengah}

Dalam Undang-Undang Nomor 20 Tahun 2008 mendefenisikan Usaha mikro Kecil dan Menengah merupakan suatu usaha milik perorangan dan atau badan usaha perorangan sifatnya produktif yang memenuhi kriteria sector mokri yang sudah diatur dalam undang-undang. Sedangkan meurut Keputusan Menteri Keuangan No. 40/KMK.06/2003 tanggal 29 Januari 2003 UMKM dapat didefenisikan sebagai berikut :

\section{Usaha Mikro}

Usaha mikro dapat diartikan sebagai usaha produktif milik keluarga atau perorangan yang berkedudukan sebagai warna negara Indonesia dengan memiliki hasil penjulan paling tinggi Rp100.000.000 pertahun. Serta dapat mengajukan kredit di bank paling tinggi adalah Rp50.000.000

\section{Usaha Kecil}

Menurut Undang-Undang No. 9 Tahun 1995, usaha kecil adalah usaha produktif yang berskala kecil dan memilki kekayaan bersih paling banyak Rp. 200.000.000, tidak termasuk tanah dan bangunan tempat usaha atau memiliki hasil penjualan paling banyak Rp. 1.000.000.000 pertahun 
serta dapat menerima kredit dari Bank diatas Rp. 50.000.000 sampai Rp 500.000.000 Juta

\section{Usaha Menengah}

Menurut Instruksi Presiden Republik Indonesia Nomor 10 Tahun 1999, usaha menengah adalah Usaha bersifat produktif yang memenuhi kriteria kekayaan bersih lebih besar dari Rp 200.000.000 (dua ratus juta rupiah) sampai dengan paling banyak sebesar Rp 10.000.000.000 (sepuluh milyar rupiah) tidak termasuk tanah dan bangunan tempat usaha.

\section{Pendapatan Usaha}

Karlina (2010) menyebutkan bahwa penghasilan dapat diartikan sebagai sebagai pendapatan dari hasil usaha, yaitu penghasilan dari kegiatan operasional normal maupun diluar normalnya pada suatu perusahaan. Sedangkan pendapatan merupakan penghasilan yang bersumber dari aktivitas perusahaan dalam melakukan operasional seperti penjualan, royalti, dividen, dan lain sebagainnya.

Dalam dunia usaha, pendapatan selalu diperoleh dalam bentuk nominal uang. Selanjutnya uang tersebut dapat digunakan untuk mengukur sejauh mana pendapatan perusahaan dalam memperoleh pendapatan dari hasil penjualan dengan mengharap keuntungan sesuai dengan tujuan yang telah dicita-citakan. Simmel menyatakan bahwa uang begitu penting dalam kehidupan, baik untuk kebutuhan hidup dalam masyarakat modern maupun untuk kebutuhan bisnis. Simmel lebih jauh lagi menjelaskan bahwa uang dalam peranya tidak hanya sebagai alat tukar akan tetapi juga sebagai penentu hubungan antar manusia (Hapiz, 2015).

\section{Modal Sendiri}

Menurut (Tohar. 2000) mendefisinikasn modal sendiri adalah modal yang sumber pendapatanya diperoleh dari perusahaan itu sendiri yaang ditanam dan untuk kebutuhan investasi. Untuk kepentingan operasonal, maka dibutuhkan sejumlah modal. Modal tersebut akan digunakan sebagai kebutuhan usaha, baik untuk investasi, pembelian aktiva, sampai pada penggunaan modal kerja. Salah satu sumber modal yang digunakan untuk investasi, pembelian bahan dan pembelian aktiva adalah modal sendri.

Modal sendiri pada dasarnya modal yang berasal dari pemilik usaha dan tertanam pada waktu yang tidak dapat ditentukan waktunya (Riyanto. 2008). Penggunaan modal sendiri sangat jauh dari resiko kerugian hal ini perusahaan tidak dibebankan dengan sejumlah utang yang menjadi tanggungjawab perusahaan untuk membayarnya. Dalam menggunakan modal sendiri, mengandung kelebihan dan ada kekurangan yang dihadapi. Salah satu kelebihan dalam menggunakan modal sendiri adalah jauh dari resiko kerugian karena tidak ada biaya kredit dan bungan yang menjadi tanggung jawab perusahaan, tidak tergantung pada pihak lain, dan tidak ada keharusan untuk mengembalikan modal.

Namun selain kelebihan diatas, ada beberapa kelemahan yang dari modal sendiri yaitu jumlah yang dibutuhkan sangat terbatas jika dibanding dengan menggunakan utang dari luar, kurangnya motivasi kerja karena tidak ada beban yang ditanggung oleh usaha. Hal ini akan mempengaruhi pendapatan usaha yang akan diperoleh dalam setiap periode tertentu. Dalam penelitian yang dilakukan oleh Saragih \& Nasution (2015) dengan hasil penelitian bahwa peningkatan modal sendiri akan mempengaruhi tingkat pendapatan hasil usaha di sektor Usaha Mikro Kecil dan Menengah (UMKM).

\section{Kredit Usaha Rakyat}

Dalam dunia usaha, sumber permodalan yang digunakan untuk keperluan operasional tidak terlepas dari pemnafaatan modal asing atau kredit. Kasmir (2013) mendefisikan kredit sebagai pemberian modal yang disediakan oleh bank yang didasarakan atas kesepakatan antara pihak pemberi modal dengan penerima modal dalam hal pengembalian uang pinjaman pada jangka waktu tertentu atau dalam bentuk bagi hasil. Sedangkan menurut Umam (2016) kredit merupakan proses pinjam memnjam yang dilakukan berdasarkan sistem syariah.

Kredit Usaha Rakyat dapat diartikan sebagai sumber modal bagi para pelaku Usaha Mikro Kecil dan Menengah yang dapat dimanfaatkan 
untuk pengadaan fasilitas usaha yang akan digunakan sebgai proses produksi. KUR merupakan program yang dicanangkan oleh pemerintah yang diperuntuhkan bagi pelaku usaha disektor Usaha Mikro Kecil dan Menengah (UMKM) yang sumber modalnya berasal dari perbankan.

Proses penyaluran KUR, pemerintah membuat suatu aturan yang termuat dalam Peraturan Menteri Keuangan No. 135/PMK.05/2008 mengenai fasilitas penjaminana fasilitas kredit usaha rakyat yang sudah menglami perubahan dengan Peraturan Menteri Keuangan No. 10/PMK.05/2009. Adapun syarat-syarat ketentuan kredit yang dimaksud adalah sebagai berikut: 1. UMKM-K yang dapat menerima fasilitas penjaminan adalah usaha produktif yang feasible namun belum bankable sebagaimana dimaksud Pasal 3 ayat (1), dengan ketentuan:

a. merupakan debitur baru yang belum pernah mendapat kredit/pembiayaan dari perbankan yang dibuktikan dengan hasil Bank Indonesia Checking pada saat Permohonan Kredit/Pembiayaan diajukan dan/atau belum pernah memperoleh fasilitas Kredit Program dari Pemerintah;

b. khusus untuk penutupan pembiayaan KUR antara tanggal Nota Kesepakatan Bersama (MoU) Penjaminan KUR dan sebelum addendum I (tanggal 9 Oktober 2007 s.d. 14 Mei 2008), maka fasilitas penjaminan dapat diberikan kepada debitur yang belum pernah mendapatkan pembiayaan kredit program lainnya;

c. KUR yang diperjanjikan antara Bank Pelaksana dengan UMKM-K yang bersangkutan.

2. Kredit/pembiayaan yang disalurkan kepada setiap UMKM-K baik untuk kredit modal kerja maupun kredit investasi, dengan ketentuan :

a. setinggi-tingginya sebesar Rp5.000.000 (lima juta rupiah) dengan tingkat bunga kredit/margin pembiayaan yang dikenakan maksimal sebesar/setara 24\% (dua puluh empat persen) efektif per tahun. b. diatas Rp5.000.000,00 (lima juta rupiah) sampai dengan Rp500.000.000,00 (lima ratus juta rupiah) dengan tingkat bunga kredit/margin pembiayaan yang dikenakan maksimal sebesar/setara 16\% (enam belas persen) efektif per tahun.

3. UMKM-K yang telah mendapatkan KUR dapat menerima fasilitas penjaminan dalam rangka perpanjangan, restrukturisasi, dan tambahan pinjaman dengan syarat masih dikategorikan belum bankable.

\section{Metode Penelitian}

Jenis penelitian yang dilakukan adalah deskriptif kuantitatif. Serta menjelaskan hubungan antara variabel melalui pengujian hipotesis dengan menggunakan data yang diuji melalui uji statistik (Kuncoro, 2009). Populasi dalam penelitian ini adalah UMKM yang ada di Desa Platihan Kidul sedangkan sampel yang digunakan adalah para pelaku Usaha Mikro Kecil dan Menengah. Pengambilan sampel dalam penelitian ini dengan membagikan kuesioner pada para pelaku Usaha Mikro Kecil dan Menengah yang ada di Desa Paltihan Kidul Kecamatan Siman Kab. Ponorogo Jawa Timur. Metode analisis yang digunakan adalah analisis regresi linear berganda.

\section{Hasil dan Pembahasan}

\subsection{Hasil Penelitian}

Untuk mengetahui ada tidaknya pengaruh variabel bebas (independen) terhadap variabel terikat (dependen) di dalam penelitian ini,maka dilakukan analisis uji regresi. Berdasarkan hasil pengolahan data maka di ketahui hasil untuk analisis regresi linear berganda dapat dilihat pada Tabel 1.

Tabel 1. Hasil Regresi Linear Berganda

\begin{tabular}{lcccc}
\hline \multicolumn{1}{c}{ Model } & Koef. & $\begin{array}{c}\text { Std. } \\
\text { Error }\end{array}$ & $\begin{array}{c}\mathrm{t} \\
\text { hitung }\end{array}$ & Sig \\
\hline $\begin{array}{l}\text { (Constant) } \\
\text { Modal }\end{array}$ & 0,461 & 0,592 & 0,780 & 0,441 \\
$\begin{array}{l}\text { Sendiri } \\
\text { Modal }\end{array}$ & 0,289 & 0,126 & 2,295 & 0,027 \\
Asing & 0,587 & 0,116 & 5,042 & 0,000 \\
\hline
\end{tabular}


Tabel 1 hasil pengujian model regresi terhadap variabel independent, menunjukan bahwa kedua variabel independent yaitu variabel modal sendiri dan variabel modal asing berpengaruh signifikan yaitu lebih kecil dari 0,05. Denga demikian, dapat dituliskan persamaannya:

Pendapatan Usaha $=0.461+0,289$ Modal Sendiri +0.589 modal sendiri.

Dari model persamaan regresi tersebut dapat di jelaskan sebagai berikut:

1. Konstanta sebesar 0.461 menyatakan bahwa jika variabel independen dianggap konstan, maka rata-rata pendapatan sebesar $0.461 \%$

2. Koefisien regresi modal sendiri adalah sebesar 0.289. Nilai koefisien positif menunjukkan bahwa modal sendiri berpengaruh positif terhadap pendapatan usaha. Artinya bahwa jika modal sendiri meningkat $1 \%$ maka akan meningkatkan pendapatan usaha sebesar $0.289 \%$.

3. Koefisien regresi modal asing adalah sebesar 0.587. Nilai koefisien positif menunjukkan bahwa modal asing berpengaruh positif terhadap pendapatan usaha. Artinya bahwa jika modal asing meningkat $1 \%$ maka akan meningkatkan pendapatan usaha sebesar $0.587 \%$.

\section{Koefisien Determinasi $\left(\mathbf{R}^{2}\right)$}

Koefisien determinasi $\left(\mathrm{R}^{2}\right)$ mengukur seberapa jauh kemampuan veriabel independent dalam mempengaruhi variabel dependent. Sehingga dengan nila yang diperoleh akan menjadi sebuah informasi terhadap faktor-faktor yang mempengaruhi variabel dependent (Imam Ghozali, 2011). Hasil perhitungan koefisien determinasi dapat dilihat pada Tabel 2.

Tabel 2. Koefisien Determinasi

\begin{tabular}{crrr}
\hline Model & R & R Square & $\begin{array}{c}\text { Adjusted R } \\
\text { Square }\end{array}$ \\
\hline 1 & $0,755^{\mathrm{a}}$ & 0,570 & 0,547 \\
\hline
\end{tabular}

Hasil analisis pada Tabel 2 menunjukan besarnya pengaruh variabel independen terhadap variabel dependen adalah sebesar 57\%. Hal ini dapat disimpulkan bahwa pengaruh variabel modal sendiri dan modal asing terhadap penda- patan usaha sebesar $57 \%$ dan sisanya $43 \%$ dipengaruhi oleh faktor lain yang tidak dimasukan dalam model regresi.

\subsection{Pembahasan}

\section{Modal Sendiri terhadap Pendapatan Usaha}

Berdasarkan hasil penelitian dan pengujian hipotesis diperoleh bahwa modal sendiri berpengaruh positif dan signifikan terhadap pendapatan usaha pada sektor Usaha Mokri Kecil dan Menengah (UMKM). Hasil penelitian ini sesuai dengan penelitian yang dilakukan oleh Saragih \& Nasution (2015) bahwa modal sendiri berpengaruh positif signifikan terhadap pendapatan usaha pada sektor Usaha Mikro Kecil dan Menengah (UMKM).

Semakin tinggi modal sendiri yang digunakan untuk keperluan investasi maka pendapatan yang diperoleh semakin besar dari hasil investasi yang dilakukan. Begitupun sebaliknya, jika modal sendiri jumlahnnya relatif sedikit maka pendapatan usaha yang akan diperoleh akan semakin sedikit pula sehingga return dari hasil investasi yang dilakukan akan rendah pula. Sehingga untuk memaksimalkan keuntungan yang diperoleh oleh pelaku usaha, maka sebaiknnya modal investasi yang dibutuhkan akan semakin besar. Untuk mengatasi adanya keterbatasan modal, sebaiknnya pelaku usaha memenfaatkan modal utang untuk menambah nilai investasinnya demi untuk memaksimalkan pendapatan usaha yang akan diperoleh. Pengaruh modal sendiri terhadap peningkatan pendapatan usaha sangat tinggi, dimana dapat kita lihat dari nilai r-square yaitu sebesar 57\%. Hal ini membuktikan bahwa membuktikan besarnnya pendapatan usaha dipengaruhi oleh besar kecilnnya nilai investasi terhadap modal sendiri.

Hasil penelitian ini sesuai dengan penelitian yang dilakukan oleh Saragih \& Nasution (2015) bahwa modal sendiri berpengaruh positif signifikan terhadap pendapatan usaha pada sektor Usaha Mikro Kecil dan Menengah (UMKM).

\section{Modal Utang terhadap Pendapatan Usaha}

Berdasarkan hasil penelitian dan pengujian hipotesis diperoleh bahwa modal yang sumbernya dari pinjaman (KUR) berpengaruh positif dan signifikan terhadap pendapatan usaha pada 
sektor Usaha Mokri Kecil dan Menengah (UMKM).

Semakin besar jumlah pinjaman modal (KUR) maka pendapatan usaha yang diperoleh akan semakin besar pula (Anggraini dan Nasution 2012). Dalam hal ini, peran pinjaman modal usaha untuk keperluan investasi sangat menentukan terhadap besarnya pendapatan yang akan diperoleh. Pada umumnnya pelaku usaha memanfaatkan modal kredit usaha rakyat (KUR) akan digunakan untuk keperluan perluasan usaha, modal kerja, dan lain sebagainnya yang berhubungan dengan kegiatan bisnis yang dilakukan.

Keuntungan lain dalam menggunakan modal pinjaman adalah meningkatnya motivasi kerja dan selalu memanfaatkan waktu yang ada untuk selalu bekerja. Sujarweni \& Utami (2015) dalam penelitianya mengemukakan bahwa penggunaan modal usaha yang bersumber dari KUR dapat meningkatkan kinerja pada usaha di sektor UMKM. Hal ini terjadi sebagai akibat dari penggunaan modal pinjaman yang mengandung resiko terhadap nilai bunga dan besaran angsuran yang disetor setiap bulannya. Dengan entitas kerja yang selalu ditingkatkan maka pendapatan usaha yang diperolehnya selalu meningkat.

Hasil penelitian ini sesuai dengan penelitian yang dilakukan oleh Anggraini dan Nasution. (2012), Saragih \& Nasution (2015) bahwa modal pinjaman (KUR) berpengaruh positif signifikan terhadap pendapatan usaha pada sektor Usaha Mikro Kecil dan Menengah (UMKM).

\section{Pendapatan Usaha sebelum dan sesudah Menggunakan Modal Utang (KUR)}

Berdasarkan pada data sebelumnnya tentang penggunaan modal usaha yang sumbernya dari modal sendiri dan modal pinjaman dari KUR, jika dilihat dari sisi pendapatan usaha mereka antara sebelum dan setelah menggunakan kredit. Penggunaan modal sendiri dan modal pinjaman (KUR) masing-masing memiliki unsur kelebihan dan kekurangan. Jika menggunakan modal sendiri, tidak memiliki beban dan resiko terhadap pengembalian modal berikut dengan bungan yang ditanggung. Namun, modal yang dimiliki sifatnya terbatas dan untuk motivasi kerja berbeda dengan orang yang sumber modal usahannya sumbernya dari modal pinjaman. Sedangkan menggunakan modal pinjaman dari KUR, memiliki resiko terhadap tidak terbayarnya angsuran beserta bunga yang dibebankan. Dari segi jumlah, modal pinjaman tak terbatas jumlahnya sehingga sangat tepat untuk keperluan ekspansi usaha. Dengan demikian pendapatan yang diperoleh akan bertambah.

Sujarweni \& Utami (2015) dalam penelitianya menjelaskan bahwa penggunaan modal pinjaman dari KUR untuk kebutuhan usaha memiliki hubungan positif signifikan terhadap pengembangan usaha. Hal ini dapat dilihat dari perubahan kinerja yang semakin meningkat sehingga pendapatan yang diperoleh semakin meningkat. Oleh karena itu, setiap para pelaku usaha UMKM khususnya di desa Patihan Kidul dan seluruh masyarakat Ponorogo pada umumnya dalam rangka mengembangkan usaha untuk selalu memanfaatkan sumber modal pinjaman dari KUR yang cara memperolehnnya mudah dan dengan bunga yang rendah.

\section{Kesimpulan}

Modal sendiri berpengaruh positif signifikan terhadap pendapatan usaha pada usaha disektor UMKM. Hal ini dapat diartikan bahwa semakin tinggi modal investasi untuk membiaya usahanya akan meningkatkan pendapatan yang akan diperoleh. Modal pinjaman dari KUR berpengaruh signifikan terhadap pendapatan usaha disektor usaha UMKM. Hal ini dapat diartikan bahwa jika utang dimanfaatkan sebaik mungkin akan meningkatkan nilai pendapatan yang akan diperoleh.

Nilai pendapatan yang diperoleh sebelum dan sesudah penggunaan modal pinjaman semakin meningkat. Hal ini dapat dilihat dari pengakuan responden terhadap pemanfaatan utang yang dapat memaksimalkan keuntungan yang diperolehnnya.

\section{Ucapan Terimakasih}

Penulis mengucapkan terimakasih kepada Fakultas Ekonomi, Universitas Muhammadiyah 
Ponorogo yang telah mendukung selesainya penelitian ini.

\section{Daftar Pustaka}

Anggraini, D., \& Nasution, S. H. (2013). Peranan kredit usaha rakyat (KUR) bagi pengembangan UMKM di Kota Medan (studi kasus Bank BRI). Ekonomi dan Keuangan, 1(3).

Hapiz, T. M. (2015). Hubungan Tingkat Modal Sosial Terhadap Tingkat Pendapatan Pelaku UKM. Jurnal Mahasiswa Sosiologi, 3(2).

Karlina, Anisa. 2010. Penerapan PSAK Nomor 23 dalam Pengakuan dan Pengukuran Pendapatan Pada PT. Prodia Widyahusada Wilayah-1 Medan.

Kasmir, (2013). Analisis Laporan Keuangan, PT RajaGrafindo Persada, Jakarta.

Kuncoro, M. (2009). Metode Riset Untuk Bisnis dan Ekonomi Bagaimana Meneliti dan Menulis Tesis?, Edisi 3. Erlangga: Jakarta

Partomo, T. dan Soejodono, A. (2004). Ekonomi Skala Kecil/Menengah dan Koperasi. Jakarta: Ghalia

Peraturan Menteri Keuangan NOMOR : 10/PMK.05/2009 Perubahan Atas Peraturan Menteri Keuangan Nomor 135/Pmk.05/2008 Tentang Fasilitas Penjaminan Kredit Usaha Rakyat.
Riyanto B. 2008. Dasar-Dasar Pembelanjaan Perusahaan. BPFE. Yogyakarta

Saragih, I. P., \& Nasution, S. H. (2015). Analisis Pengaruh Modal Sendiri dan Modal Pinjaman Kredit Usaha Rakyat (KUR) terhadap Pendapatan Pengusaha UMKM Kabupaten Toba Samosir: Studi Kasus PT Bank Sumut Cabang Balige. Jurnal Ekonomi dan Keuangan, 3(7).

Sujarweni, V. W., \& Utami, L. R. (2015). Analisis Dampak Pembiayaan Dana Bergulir KUR (Kredit Usaha Rakyat) terhadap Kinerja UMKM (Studi Kasus di Daerah Istimewa YOGYAKARTA). Jurnal Bisnis dan Ekonomi, 22(1)

Tohar, M. (2000). Membuka Usaha Kecil. Prenhallindo. Jakarta

Umam, K. (2016). Perbankan Syariah. Jakarta: PT Raja Grafindo Persada.

Undang-Undang Nomor 20 Tahun 2008 tentang Usaha Mikro, Kecil, Dan Menengah.

Wahyuni, Eti, dkk, 2005. Lilitan Masalah Usaha Mikro, Kecil, Menengah (UMKM) \& Kontroversi Kebijakan. Medan: BITRA Indonesia

Wiratna V.S dan Utami, L. R., (2013). Analisis Dampak Pembiayaan Dana Bergulir Kur (Kredit Usaha Rakyat) Terhadap Kinerja Umkm. Jurnal Bisnis dan Ekonomi (JBE). Vol. 22 No. 1 Maret 2015 